\title{
The effect of method of handling and season on weight loss, water holding capacity and colour quality of beef sold in Imo State, Nigeria.
}

Nwafor, I. C., Okoli, I. C and N. J. Okeudo*

Department of Animal Science and Technology, Federal University of Technology, P.M.B 1526, Owerri, Nigeria.

*Corresponding author: nokeudo@yahoo.com; Tel: +2348036753146

\begin{abstract}
The objective of this study was to determine the influence of handling method and season on water holding capacity, weight loss, cooking loss and colour of retail beef. Four handling methods which corresponded to the commercial methods of handling retail meat were selected. They were beef sample kept uncovered on the butchers table (Treatment A); beef sample kept uncovered and under room temperature but not on the butcher's table in order to prevent customers from handling it (Treatment B); beef sample exposed to sunlight (Treatment C); and beef sample kept on top of ice in a covered cooler (Treatment D). Samples were kept from $09.00 \mathrm{hrs}$ till $18.00 \mathrm{hrs}$ on sampling days. The experiment was replicated 3 times in each of the two seasons (rainy and dry seasons), with an interval of 7 days between sampling. Percentage water holding capacity (\% WHC) was neither affected by season nor handling method $(P>0.05)$. However, the mean $\%$ WHC for the rainy season beef samples was slightly higher than that for the dry season counterparts. Percentage weight loss (\% WL) showed significant differences $(P<0.05)$ between the four handling methods within and between the seasons. Similarly, the handling methods and season had significant effects $(P<0.05)$ in percentage cooking loss $(\% \mathrm{CL})$ and subjective colour score (SCC). Significant and positive linear relationship was observed between atmospheric humidity and WHC $(R=0.807 ; P<0.05)$. There was also significant and positive linear correlation between atmospheric temperature and $W L(R=0.857 ; P<0.05)$.
\end{abstract}

Keywords: Beef, Handling method, Season, Humidity, Temperature and Meat quality

\section{Introduction}

Meat and meat products belong to different classes and types, and vary in quality. Differences in quality depend on variations in physical, chemical, morphological, biochemical, microbial, sensory, technological, hygienic, nutritional and culinary properties (Ingr, 1989). Appearance, texture, juiciness, wateriness, firmness, tenderness, odour and flavour are among the most important and perceptible meat features that influence the initial and final quality judgment by consumers before and after purchasing a meat product (Cross et al., 1986; Barbut, 1996). Furthermore, quantifiable properties of meat such as water holding capacity, shear force, drip loss, cooking loss, $\mathrm{pH}$, shelf life, collagen content, protein solubility, cohesiveness, and fat binding capacity are important to processors involved in the manufacture of value added meat products (Allen et al., 1998). Raw meat used in further processed products is required to have excellent functional properties that will ensure a final product of exceptional quality and profitability.

In Nigeria, cattle is the most important source of meat, and its production and in deed all ruminant production as well as meat merchandise are relatively under developed (Okeudo, 2004; Okoli et al., 2005). Approximately $90 \%$ of cattle 
production is in the hands of Nomadic Fulanis and even when urban dwellers own cattle, they still employ the Fulanis to manage them (Oyeleye, 1981). Urban dwellers consume more than $60 \%$ of what is slaughtered every day. In most parts of the country, animals trek to the markets often with inadequate feeding and watering, and under considerable stress which result in losses of both volume and quality of meat. Majority of animals for slaughter are transported from the north where they are reared to the south by road and in trucks. Journey time is often in days and without rest and feeding. In the process, considerable losses in weight and in all likelihood mortality should be expected. Often animals trek for long distances to the point of slaughter, and are killed on arrival without rest (Okeudo, 2004). Shortage of trained personnel, skilled producers, processors, distributors, extension advisers and technicians add to the constraints on meat production in Nigeria. Lack of qualified control personnel and veterinarians, refrigeration and other preservation facilities lead to enormous losses in quality and quantity of livestock products and may also result in health problems to consumers (Okoli et al., 2005). Very little of the daily output from slaughter is kept longer than 24 hours because preservation facilities are either nonexistent or not functioning due to poor maintenance or poor and epileptic electric power supply. The vast majority of meat is retailed on butchers' tables, without packaging or covering, in the open market, and exposed to the atmosphere. Prospective buyers are allowed to handle the fresh meat cut in order to gauge the weight as the selling price is negotiated. Some retailers are known to move about hawking fresh meat that is exposed to direct sunlight. The deleterious effects of such commercial practices on product quality depreciation can be quite enormous.

This research work was designed to investigate the effect of the different ways beef is handled whilst it is retailed on water holding capacity, weight loss, cooking loss and colour quality. This study was conducted in each of the two seasons (rainy season and dry season) in Owerri town, Southeastern Nigeria. In addition, linear correlations between these parameters and climatic factors (humidity and temperature) were determined.

\section{Materials and methods Description of study area and period} This study was conducted in Owerri, Imo State, which is located within the Southeastern part of Nigeria. Imo State lies between Latitude $4^{\circ} 4^{\prime}$ and $6^{\circ} 3^{\prime} \mathrm{N}$ and Longitude $6^{\circ} 15^{\prime}$ and $8^{\circ} 15^{\prime}$ E. The vegetation formation is rain forest with a warm humid tropical climate. There are two main climatic seasons each year - the rainy season and the dry season. In Owerri, the former began in May and ended in October, whilst the latter in November and April, respectively (Min. of Lands and Survey, Imo State, 1984).

\section{Sample collection}

This study took place in the two seasons, in the months of October for the rainy season, and December and January for the dry season. The samples were obtained from Owerri Abattoir between 07.00 and 08.00 am on sampling days. A beef carcass was selected randomly and meat samples from the $3^{\text {rd }}-12^{\text {th }}$ rib section of the Longissimus dorsi (LD) muscle were taken from both carcass sides. The two LD muscle samples were each subdivided into 2 , giving 4 muscle samples. The samples were labeled $\mathrm{A}, \mathrm{B}, \mathrm{C}$ and $\mathrm{D}$ and placed inside clean polythene bags which were immediately taken to a nearby foodstuff market in an ice 
packed cooler. Journey time was about 15 min. Sample A was placed on the butcher's table in the market (room temperature storage). Prospective buyers were allowed to handle it. Sample B was placed in an open container and kept on the floor behind the butcher's table (room temperature storage). Thus, prospective buyers were prevented from handling it. Sample C was placed in a tray and exposed to direct sunshine, whereas Sample D was kept inside a covered ice-packed cooler. All samples were kept as described above from $09.00 \mathrm{hrs}-18.00 \mathrm{hrs}$ during which determinations for weight loss and water holding capacity were carried out at intervals of $1.30 \mathrm{hrs}$. In each season, samplings and measurements were replicated three times, at intervals of 7 days. Percentage weight loss (\% WL) determination

An electronic scale (Kenwood $5 \mathrm{~kg}$ Dunstable $^{\mathrm{R}}$, UK) was used to weigh the different samples under the different handling methods at $09.00,10.30,12.00$, $13.30,15.00,16.30$ and $18.00 \mathrm{hrs}$. The difference between the sample weight at $09.00 \mathrm{hrs}$ and the weight at any subsequent weighing was calculated and expressed as a percentage of the sample weight at 09.00 hrs. This gave percentage cumulative weight loss ( $\% \mathrm{WL})$. In order to determine the rate of weight loss at a particular time in the day, the sample weight at that time was subtracted from the preceding sample weight, and the difference expressed as a percentage of that preceding sample weight.

Percentage water holding capacity (\% WHC) determination

Water holding capacity determination was carried out following the method described by Honikel (1998). About $10 \mathrm{~g}$ each of the samples A, B, C and D were cut, weighed and wrapped individually with paper towel.
Each sub-sample was crushed with a screw jack. Moisture squeezed out by the crushing process was absorbed by the paper towel and thereafter the residual meat sample was re-weighed. This was done 7 times at 9.00, $10.30,12.00,13.30,15.00,16.30$ and 18.00 hrs. The difference in weight of the fresh meat sample before $\left(\mathrm{W}_{1}\right)$ and after crushing $\left(\mathrm{W}_{2}\right)$ was divided by the weight before crushing $\left(\mathrm{W}_{1}\right)$ and the fraction was transformed into percentage points giving the percentage water holding capacity $(\%$ WHC):

$\% \mathrm{WHC}=\left[\left(\mathrm{W}_{1}-\mathrm{W}_{2}\right) / \mathrm{W}_{1}\right] \times 100$

Furthermore, the average \% WHC for each handling method was calculated for each day.

\section{Subjective colour assessment (SCA)}

The final colour of samples A, B, C and D at $18 \mathrm{hrs}$ were assessed subjectively according to guidelines published by AMSA (2012) with modification. Samples were assessed by a panel of 10 persons based on a 5 point colour rating scale namely: 5 - Highly acceptable colour; 4 - Moderately acceptable colour; 3 - Slightly acceptable colour; 2 - Slightly unacceptable colour and 1 -Unacceptable colour.

Percent cooking loss (\% CL) determination

After $18.00 \mathrm{hrs}$, about $30 \mathrm{~g}$ each of samples A, B, C and D were cut and weighed. They were wrapped in transparent polythene bags with appropriate tags and cooked for 30 mins in hot water at boiling point. They were allowed to cool and the final weights were determined. The cooking loss (CL) was determined for each treatment using the formula:

$$
\text { CL (\%) }=\frac{\text { Fresh wt }- \text { Cooked wt }}{\text { Fresh wt }} \times \frac{100}{1}
$$

\section{Humidity and Temperature determination}

The maximum air temperatures and humidity of sampling days were obtained from recordings made at the Department of 
Geography, Alvan Ikoku Federal College of Education, Owerri, Imo State. Correlations between the different parameters and temperature / humidity values were determined for each season.

\section{Statistical Analyses}

A completely randomized $2 \times 4$ factorial design was employed. It includes 2 seasons and 4 handling methods. Effects of handling method and season were determined by analysis of variance (ANOVA) based on the normal F-test (Little and Hills, 1978). Thereafter all the data were pooled together and the effect of season was determined using the $\mathrm{T}$ test. Correlations between atmospheric temperature and humidity values as independent variates and meat quality parameters as dependent variates were determined. All computations were executd on the SAS workstation while mean separation was achieved using the least significant difference test.

\section{Results and Discussion}

Table 1 shows the temperature and humidity records for the three days in both rainy and dry seasons when beef samples were collected. On these days, the humidity varied from $77 \%$ to $81 \%$ with an average of $79.67 \%$ during the rainy season whilst corresponding temperature records varied from $30^{\circ} \mathrm{C}$ to $31{ }^{\circ} \mathrm{C}$ with an average of 30.67 ${ }^{0} \mathrm{C}$. The dry season humidity and temperature records for the three days varied from $61 \%$ to $67 \%$ and $31{ }^{\circ} \mathrm{C}$ to $32{ }^{\circ} \mathrm{C}$ averaging $64.00 \%$ and $31.67{ }^{\circ} \mathrm{C}$, respectively.

There were no significant differences $(\mathrm{P}>0.05)$ in \% WHC between the four handling methods, within and between the seasons (Table 2). However, the mean \% WHC of the rainy season samples was 13.6 $\%$ higher than their dry season counterparts. This may be due to the significantly higher weight loss by the dry season samples compared to the rainy season counterparts. Results from published literature on WHC of beef produced in the tropics are not available; however, Okeudo et al. (2007) reported that the water holding capacity of meat from boars and gilts were $53.9 \%$ and $46.8 \%$, respectively, which were considerably higher than $11.10 \%-16.59 \%$ observed in this study. This suggests that considerable differences in WHC exist for

Table 1: Mean temperature and humidity of sampling days for rainy and dry seasons.

\begin{tabular}{|c|c|c|c|c|c|c|c|}
\hline \multirow[t]{2}{*}{ Season } & \multirow{2}{*}{$\begin{array}{l}\text { Sampling } \\
\text { Day }\end{array}$} & \multirow[t]{2}{*}{ Hum (\%) } & \multirow[t]{2}{*}{ Temp $\left({ }^{0} \mathrm{C}\right)$} & \multicolumn{2}{|c|}{ Hum (\%) } & \multicolumn{2}{|c|}{ Temp $\left({ }^{0} \mathrm{C}\right)$} \\
\hline & & & & Mean & SEM & Mean & SEM \\
\hline \multirow[t]{3}{*}{ Rainy } & 1 & 77 & 31 & & & & \\
\hline & 2 & 81 & 30 & & & & \\
\hline & 3 & 81 & 31 & $79.67^{\mathrm{a}}$ & 1.333 & $30.67^{b}$ & 0.333 \\
\hline \multirow[t]{3}{*}{ Dry } & 1 & 67 & 31 & & & & \\
\hline & 2 & 64 & 32 & & & & \\
\hline & 3 & 61 & 32 & $64.0^{\mathrm{b}}$ & 1.732 & $31.67^{\mathrm{a}}$ & 0.333 \\
\hline
\end{tabular}

${ }^{\mathrm{a}, \mathrm{b}}$ Means within a column with a similar superscript are not significantly different $(\mathrm{P}>0.05)$

Temp. - Temperature, Hum. - Humidity. 
different livestock species. Based on the above results, it can be inferred that neither season nor the handling methods had a significant effect on the water holding capacity of beef.

Water holding capacity is an important indicator of technological or manufacturing quality of meat as it positively influences the yield of meat products such as sausages. WHC is highest when the ultimate $\mathrm{pH}$ $(\mathrm{pHu})$ of meat postmortem falls within the normal range ( $\mathrm{pH} 5.5-5.8)$, and decreases with increasing and decreasing $\mathrm{pHu}$ (Lawrie, 1991). Prolonged poor feeding, fasting prior to slaughter and slaughtering relatively very old cattle (conditions characteristic of the Nigerian animal industry) result in meat with low WHC (Cheng and Sun, 2008). These factors may have affected the WHC of the meat used in this study.

There were significant differences $(\mathrm{P}<0.05)$ in $\%$ WL between the four handling methods within and between the seasons (Table 2). \% WL in both seasons were highest $(\mathrm{P}<0.05)$ amongst the beef samples exposed to the sun (Treatment $C$ ), whereas it was lowest for the beef samples kept on top of ice in the covered cooler (Treatment D). It was consistently higher in the dry season for all the handling methods than the corresponding values in the rainy season. This is likely due to the lower humidity and higher temperature characteristic of the dry season in Nigeria. From the economic point of view, the high rate of weight loss would result to loss of revenue to the retailer when meat is sold in the evening hours than in morning hours. This is because it is common practice in Nigeria for prospective meat buyers to lift up the meat cut in order to gauge the weight as both parties negotiate the price. This implies that the consumer is advantaged when meat is sold in the evening. In fact, because of the scarcity of cold preservation facilities, when market closes for the day meat retailers often had to carry remaining meat to restaurant operators and dispose them at highly reduced price. Although this does not constitute a loss to the aggregate meat supply, it results to gross variation, instability and distortion in the price of meat. To minimize the rapid loss in weight, some butchers sprinkle water on the meat cuts intermittently during the day, an action that may lead to rapid microbial proliferation with the attendant negative effect on public health.

There were significant differences $(\mathrm{P}<0.05)$ between the four handling methods within and between seasons for \% CL (Table 2). The beef sample kept in the ice-packed cooler (Treatment D) showed the highest mean percent cooking loss for both seasons whereas Treatment $\mathrm{C}$ (the beef sample exposed to the sun) showed the lowest $\%$ $\mathrm{CL}$ in all handling methods for both seasons. This is attributable to increased evaporation of moisture from the beef samples exposed to the sun compared to samples in the ice-packed cooler.. Okeudo and Moss (2005) reported that cooking loss was positively correlated with moisture content in lamb muscles. Thus, the likely lower moisture content of beef samples exposed to the sun would result in lower percentage cooking loss. Crouse and Koohmaraie (1990) had earlier concluded that the release of juice from meat by heating is directly proportional to the hydration of the raw meat.

Table 2 shows that within each season there were significant differences $(\mathrm{P}<0.05)$ in SCS between the handling methods. However, between season differences were not significant $(\mathrm{P}>0.05)$. Treatments $\mathrm{A}$ and B (beef samples kept on the butcher's table and in room temperature, respectively) for both seasons were not significantly 
The effect of method of handling and season on weight loss of beef

Table 2: The effect of season and handling methods on beef physical quality parameters.

\begin{tabular}{|c|c|c|c|c|c|c|c|c|c|}
\hline \multirow[t]{2}{*}{ Season } & \multirow{2}{*}{$\begin{array}{l}\text { Handling } \\
\text { methods }\end{array}$} & \multicolumn{2}{|c|}{$\% \mathrm{WHC}$} & \multicolumn{2}{|c|}{$\% \mathrm{WL}$} & \multirow{2}{*}{$\begin{array}{l}\% \text { CL } \\
\text { Mean }\end{array}$} & \multirow[b]{2}{*}{ SEM } & \multicolumn{2}{|l|}{ SCS } \\
\hline & & Mean & SEM & Mean & SEM & & & Mean & SEM \\
\hline \multirow[t]{5}{*}{ Rainy } & A & 13.50 & 4.325 & $6.27^{\mathrm{f}}$ & 0.884 & $40.47^{\mathrm{ab}}$ & 0.606 & $4.13^{\mathrm{a}}$ & 0.033 \\
\hline & B & 16.59 & 4.402 & $4.10^{\mathrm{g}}$ & 1.277 & $42.67^{\mathrm{a}}$ & 3.453 & $4.20^{\mathrm{a}}$ & 0.321 \\
\hline & $\mathrm{C}$ & 15.76 & 1.898 & $9.60^{\mathrm{e}}$ & 1.850 & $34.00^{\mathrm{cd}}$ & 3.927 & $2.87^{b}$ & 0.167 \\
\hline & $\mathrm{D}$ & 14.93 & 4.662 & $1.30^{\mathrm{h}}$ & 0.115 & $42.80^{\mathrm{a}}$ & 1.572 & $3.00^{\mathrm{b}}$ & 0.551 \\
\hline & Mean & 15.20 & 0.659 & 5.32 & 0.753 & 39.99 & 2.065 & 3.55 & 0.356 \\
\hline \multirow[t]{5}{*}{ Dry } & A & 12.43 & 0.722 & $24.93^{\mathrm{c}}$ & 1.167 & $29.97^{\mathrm{de}}$ & 2.537 & $4.43^{\mathrm{a}}$ & 0.176 \\
\hline & B & 13.87 & 1.162 & $28.13^{\mathrm{b}}$ & 2.839 & $37.50^{b c}$ & 1.253 & $4.13^{a}$ & 0.267 \\
\hline & $\mathrm{C}$ & 16.10 & 0.493 & $35.27^{\mathrm{a}}$ & 2.243 & $27.00^{\mathrm{e}}$ & 2.977 & $3.17^{\mathrm{b}}$ & 0.260 \\
\hline & D & 11.10 & 0.208 & $21.23^{\mathrm{d}}$ & 1.135 & $39.23^{a b}$ & 3.547 & $3.60^{\mathrm{ab}}$ & 0.231 \\
\hline & Mean & 13.38 & 1.070 & 27.39 & 2.981 & 32.59 & 2.657 & 3.83 & 0.280 \\
\hline \multicolumn{10}{|c|}{$\begin{array}{l}\text { a,b,c,d,e,f,g and }{ }^{\text {h }} \text { Means in a column w } \\
\text { WHC - Water Holding Capacity, C } \\
\text { SCS - Subjective Colour Scores } \\
\text { Subjective colour scores: } \\
5 \text { = Highly acceptable colour } \\
4 \text { = Moderately acceptable colour } \\
3 \text { = Slightly acceptable colour } \\
2 \text { = Slightly unacceptable colour } \\
1 \text { = Unacceptable colour }\end{array}$} \\
\hline
\end{tabular}

different $(\mathrm{P}>0.05)$ but exhibited a more acceptable visual colour quality than Treatments C and D samples (beef samples exposed to the sun or kept on top of ice in a covered cooler, respectively). The lower colour quality exhibited by samples exposed to direct sunlight was probably due to desiccation of the meat surface and rapid conversion of myoglobin to metmyoglobin by the ultra-violet rays from sunlight. Lawrie (1991) noted that depreciation of meat colour quality due to metmyoglobin formation is accelerated by conditions like ultra-violet irradiation, salt and heat application. Secondly, it is known that when fresh meat is kept in a covered vessel, the continued cellular respiration rapidly depletes the oxygen content in the air around the meat resulting in the preponderance of reduced purplish myoglobin with lower colour quality (Ledward, 1992; Seideman et al., 1984). In this study, the meat samples kept on ice in a covered cooler were not given sufficient time to bloom and this in all likelihood explains their poorer colour. Of course leaving them longer under atmospheric temperature as measurements were 
periodically carried out would negate the effect of cold storage. Nevertheless, it could also be that the consumers were used to colour of exposed fresh meat and therefore would score it high in colour quality compared to meat handled differently.

Since meat colour is an important parameter which connotes freshness to buyers (Lawrie, 1991), the above result shows that local meat buyers may be attracted to beef samples kept on the butchers table and at room temperature, respectively than beef samples exposed to the sun or covered.

Results in Table 3 showed that there were significant linear correlations between humidity and some of the parameters. Significant linear relationship was detected between humidity and water holding capacity $(\mathrm{R}=0.807 ; \mathrm{P}<0.05)$. Another parameter that showed high correlation and was close to statistical significance was weight loss $(\mathrm{R}=-0.690 ; \mathrm{P}=0.065)$, This suggests that increase in humidity is associated with increase in water holding capacity and a decrease in rate of weight loss in meat samples. These findings should find relevance in quality retention and prolongation of shelf life during meat storage.

Significant positive linear correlation between atmospheric temperature and weight loss $(\mathrm{R}=0.857 ; \mathrm{P}<0.05)$ was observed (Table 3). Negative significant correlations were observed between temperature and water holding capacity $(\mathrm{R}=-0.906 ; \mathrm{P}<0.05)$ and cooking loss $(\mathrm{R}=-$ $0.787 ; \mathrm{P}<0.05)$. A close examination of the magnitude of the coefficients of determination $\left(\mathrm{R}^{2}\right)$ reveals that atmospheric temperature appears to be a more important factor in this respect than atmospheric humidity since it explains $82.1 \%, 73.6 \%$ and $61.9 \%$ of the variations in water holding capacity, weight loss and cooking loss, respectively; whereas corresponding values for humidity were $65.1 \%, 47.6 \%$ and $17.5 \%$ for the same parameters. The relatively high negative relationship $(\mathrm{R}=$ $0.906, \mathrm{P}=0.006)$ ) between temperature and water holding capacity may confirm the known fact that high storage temperature (slower cooling rate) leads to greater denaturation of muscle proteins and greater exudation of meat juice (Lawrie, 1991). However, since the extent of muscle protein denaturation was not measured in this study, it may or may not be the major

Table 3: Linear correlation coefficient equations relating humidity $(\mathrm{X})$ to various beef physical parameters.

\begin{tabular}{llll}
\hline Linear equation & $\mathrm{R}$ & $\mathrm{R}^{2}$ & Significance level \\
\hline Humidity $\left(\mathrm{X}_{1}\right)$ & & \\
$\mathrm{Y}_{1}=2.59+0.16 \mathrm{X}_{1}$ & 0.807 & 0.651 & $\mathrm{P}=0.026^{*}$ \\
$\mathrm{Y}_{2}=75.35-0.88 \mathrm{X}_{1}$ & -0.690 & 0.476 & $\mathrm{P}=0.065$ \\
$\mathrm{Y}_{3}=19.32+0.25 \mathrm{X}_{1}$ & 0.418 & 0.175 & $\mathrm{P}=0.205$ \\
$\mathrm{Y}_{4}=4.90-0.01 \mathrm{X}_{1}$ & -0.270 & 0.073 & $\mathrm{P}=0.302$ \\
Temperature $\left(\mathrm{X}_{2}\right)$ & & \\
$\mathrm{Y}_{1}=82.33-2.18 \mathrm{X}_{2}$ & -0.906 & 0.821 & $\mathrm{P}=0.006^{* *}$ \\
$\mathrm{Y}_{2}=-389.48+12.89 \mathrm{X}_{2}$ & 0.857 & 0.736 & $\mathrm{P}=0.015^{*}$ \\
$\mathrm{Y}_{3}=211.60-5.59 \mathrm{X}_{2}$ & -0.787 & $\mathrm{P}=0.032^{*}$ \\
$\mathrm{Y}_{4}=1.00+0.09 \mathrm{X}_{2}$ & 0.159 & $\mathrm{P}=0.383$ \\
\hline *- significant correlation $(\mathrm{P}<0.05), * *$ - highly significant correlation $(\mathrm{P}<0.01)$ & \\
$\mathrm{R}=$ Coefficient of correlation; $\mathrm{R}^{2}=$ Coefficient of determination; $\mathrm{X}_{1}=\mathrm{Humidity} ;$ & \\
$\mathrm{X}_{2}=$ Temperature; $\mathrm{Y}_{1}=$ Water holding capacity $(\%) ; \mathrm{Y}_{2}=$ Weight loss $(\%) ;$ & \\
$\mathrm{Y}_{3}=$ Cooking loss $(\%) ; \mathrm{Y}_{4}=$ Subjective colour score &
\end{tabular}


determinant of the observed negative correlation.

Okeudo and Moss (2005) reported highly significant negative correlation between cooling rate and the cooking loss of the infraspinatus muscle. This is supported by the present results. Apparently, the significant negative relationship between atmospheric temperature and cooking loss $(\mathrm{R}=-0.787 ; \mathrm{P}=0.032)$ was indirect, but may be due to the direct effect of water holding capacity on cooking loss. Our results suggest that within the circumstance of this study, neither atmospheric temperature nor humidity had a significant relationship with subjectively determined colour quality.

\section{References}

Allen, C. D., Fletcher, D. L., Northcutt, J. K. and Rusell, A. 1998. The relationship of broiler breast color to meat quality and shelf life. Poult. Sci., 77: $361-366$.

AMSA, 2012. Meat Color Measurement Guidelines. American Meat Science

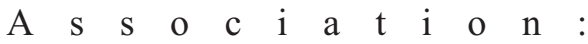
Lttp://www.meatscience.org

Barbut, S. 1996. Estimates and detection of the PSE problem in young turkey breast meat. Can. J. Anim. Sci. 76: 455 $-457$.

Brown, S. N., Bevis, E. A. and Warris, P. D. 1990. An estimate of the incidence of dark-cutting beef in the United kingdom. Meat Sci., 27: 249 - 258.

Cheng, O. and Sun, D. W. 2008. Factors affecting the water holding capacity of red meat products: a review of recent research advances. Critical Reviews in Food Science and Nutrition, 48 (2): $137-159$.

Cross, H. R., Durland, P. R. and Seideman, S. C. 1986. Sensory qualities of meat. In: Bechtel, P. J. (editor). Muscle As Food, pp 279 320; Academic Press, New York.

Crouse, J. D. and Koohmaraie, M. 1990. Effect of freezing of beef on subsequent postmortem aging and shear force: a research note. J. Food Sci. 55:573-574.

Honikel, K. O. 1998. Reference methods for the assessment of physical characteristics of meat. Meat Science, 49:447-457.

Ingr, I. 1989. Meat quality: Defining the term by modern standards. Fleisch. 69:1268.

Lawrie, R.A. 1991. Meat Science. 5th ed. Pergamon Press, New York.

Ledward, D. A. 1992. Colour of raw and cooked meat. In: Ledward, D.A., Johnston, D.E. and Knight, M.K.(editors), The Chemistry of Muscle Based Foods. pp 128-144;. Royal Society of Chemistry., Cambridge.

Little, T. M. and Hills, J. F. 1978. Agriculture experimentation: Design and Analysis. John Wiley and sons, London, UK.

Ministry of Lands and Survey, Imo State, (1984). Atlas of Imo State, Ministry of Lands and Survey, Owerri, Imo State, Nigeria.

Okeudo, N. J. 2004. Empirical studies on the living condition of domestic animals: results from Nigeria. In Amalu, U. C. and Goltwald, F. T. (editors). Studies of Sustainable Agriculture and Animal Science in sub-Saharan Africa, pp129 - 141. PETER LANG, Eüropāicher Velag de Wissenschaften

Okeudo, N. J. and Moss, B. W. 2005. Interrelationships among carcass and meat quality characteristics of sheep. Meat Sci, 69: 1 - 8. 
Nwafor, I. C., Okoli, I. C and Okeudo, N. J.

Okeudo, N. J., Aladi, N. O., Okoli, I. C. and Akanno, E. C. 2007. Comparative study of the growth and carcass characteristics of the Nigerian Indigenous and Large White Pigs. Asian J.Anim. Sci., 1(2): 57-66.

Okoli, I. C. , Aladi, N. O., Etuk, E. B., Opara, M. N., Anyanwu, G. A. and Okeudo, N. J. 2005. Current facts about the animal food products safety situation in Nigeria. Ecol. Food Nutr.,
44: $359-373$.

Oyeleye, A. K. 1981. Cattle Rearing in Western Nigeria. Livestock Health Magazine, Lagos. No. 137, Pp 25.

Seiderman, S. C., Cross, H. R., Smith, G. C. and Durland, P. R. 1984. Factors associated with fresh meat colour: a review. J. Food Qual., 6:211 - 237.

Received: $22 / 10 / 13$

Accepted: 06/02/14 